\title{
SOME DATA ON THE METABOLISM OF DIGARBOXYLIC AMINO-AGIDS AND THEIR AMIDES IN YEAST
}

\author{
S. R. Mardashev \\ Laboratory of Enzymology, Institute of Biological and Medical \\ Chemistry, Academy of Medical Sciences of the USSR, Moscow, \\ U.S.S.R.
}

\section{INTRODUCTION}

Dicarboxylic amino-acids and their amides provide a system which occupies a key position in the nitrogen metabolism of living organisms. The brilliant investigations of Barker and his associates led to the discovery of a new component of this system- $\beta$-methylaspartic acid ${ }^{1}$.

The enzymatic isomerization of glutamic into $\beta$-methylaspartic acid under the influence of $\beta$-methylaspartate-glutamate-isomerase, occurring in Clostridi:um tetanomorphum, establishes an intimate connection between these two dicarboxylic amino-acids.

All the experiments carried out in our Laboratory, which are reported here, have been undertaken with the Saccharomyces cerevesiae culture, strain XII INMI No. 46. The yeast was grown in a synthetic medium $(3 \mathrm{~g}$ $\left(\mathrm{NH}_{4}\right)_{2} \mathrm{SO}_{4} ; 0.7 \mathrm{~g} \mathrm{MgSO}_{4} \cdot 7 \mathrm{H}_{2} \mathrm{O} ; 0.4 \mathrm{~g} \mathrm{Ca}\left(\mathrm{NO}_{3}\right)_{2} ; 0.5 \mathrm{~g} \mathrm{NaCl} ; 1 \mathrm{~g} \mathrm{KH}{ }_{2} \mathrm{PO}_{4}$; $0 \cdot 1 \mathrm{~g} \mathrm{~K}_{2} \mathrm{HPO}_{4} ; 20 \mathrm{~g}$ saccharose; $\mathrm{B}_{1}, \mathrm{~B}_{6}$ and panthothenate $2.5 \mathrm{mg}$ each; biotin $0.62 \mathrm{mg} ; 1$ litre of tap water). Following centrifugation, the yeast mass was destroyed in the Hughes' press. Ammonia was determined according to Conway, amino-acids and amides by paper chromatography. Additional data on the methods employed are stated below in this paper.

\section{COMPARATIVE STUDIES ON BIOSYNTHETIC PATH- WAYS OF DICARBOXYLIG AMINO-ACIDS}

The following three pathways of glutamic, aspartic and $\beta$-methylaspartic acids biosynthesis may be assumed theoretically:

(i) amination of unsaturated dicarboxylic acids;

(ii) amination of $\alpha$-ketodicarboxylic acids;

(iii) transamination with $\alpha$-ketodicarboxylic acids.

\section{(i) Amination of unsaturated dicarboxylic acids}

$\beta$-Methylaspartase reaction (reaction $b$ ) was detected in some microbes ${ }^{2}$; in experiments with $S$. cerevesiae, however, we were unable to find any evidence for $\beta$-methylaspartate biosynthesis from mesaconate. Also we failed to accomplish glutamate biosynthesis by means of glutaconate amination 


\section{S. R. MARDASHEV}

(reaction $a$ ). It was only in experiments with fumarate (reaction $c$; see also Table 1) that positive results were obtained.

(a)<smiles>NC(CC(=O)O)[C@@H](N)CC(=O)O</smiles>

Glutaconic Glutamic acid $\mathrm{COOH}$

(c)<smiles>NC(CCCCCCC(=O)O)C(N)C(=O)O</smiles>

Fumaric acid

$$
\text { acid }
$$

Aspartic (b)<smiles>CC(C(=O)O)C(N)C(N)C(=O)O</smiles>

\section{$\beta$-Methylaspartic acid}

Mesaconic acid

Table 1. Aspartate biosynthesis from fumarate

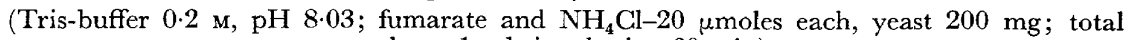
volume $1 \mathrm{ml}$; incubation $60 \mathrm{~min}$ )

\begin{tabular}{|c|c|c|c|}
\hline Composition of samples & \multicolumn{3}{|c|}{$\begin{array}{c}\text { Aspartate biosynthesis } \\
\text { (umoles) }\end{array}$} \\
\hline $\begin{array}{l}\text { (a) Fumarate } \\
\text { (b) Fumarate }+\mathrm{NH}_{4} \mathrm{Cl}\end{array}$ & $\begin{array}{c}0 \\
2 \cdot 09\end{array}$ & $\begin{array}{c}0 \\
2 \cdot 30\end{array}$ & $\begin{array}{c}0 \\
2 \cdot 37\end{array}$ \\
\hline
\end{tabular}

(ii) Amination of $\alpha$-ketodicarboxylic acids

Direct amination of $\alpha$-ketoglutaric acid catalysed by glutamate-dehydrogenase was observed in many biological objects, including yeast ${ }^{3}, 4$ :
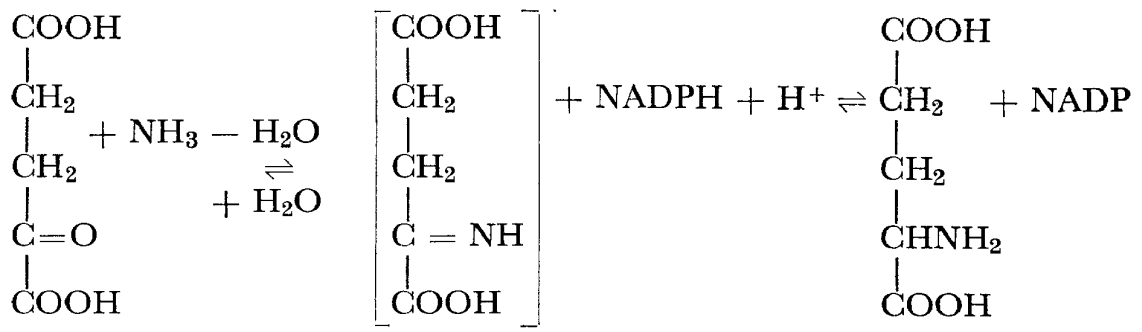

In our experiments with $S$. cerevisiae direct amination of $\alpha$-ketoglutarate could also be easily detected (Table 2). Neither oxaloacetate nor methyloxalocetate underwent direct amination, since no aspartic or $\beta$-methylaspartic acid biosynthesis from ammonium chloride and the corresponding ketoacids was observed. 


\section{JMETABOLISM OF DICARBOXYLIC AMINO-ACIDS AND THEIR AMIDES}

Talle 2. Glutamate biosynthesis from $\alpha$-ketoglutarate and ammonium chloride (Tris-buffer $0.2 \mathrm{M}, \mathrm{pH} 7.22 ; \alpha$-ketoglutarate $30 \mu$ moles; ammonium chloride $15 \mu$ moles; yeast $200 \mathrm{mg}$; total volume $1 \mathrm{ml}$; incubation $60 \mathrm{~min}$ )

\begin{tabular}{c|ccc}
\hline Composition of samples & \multicolumn{3}{|c}{$\begin{array}{c}\text { Glutamate biosynthesis } \\
\text { ( } \mu \text { moles) }\end{array}$} \\
\hline $\begin{array}{c}\text { (a) } \alpha \text {-Ketoglutarate } \\
\text { (b) } \alpha \text {-Ketoglutarate } \\
+\mathrm{NH}_{4} \mathrm{Cl}\end{array}$ & 3.64 & 3.12 & 2.87 \\
\hline
\end{tabular}

\section{(iii) Transamination with $\alpha$-ketodicarboxylic acids}

Biosynthesis of amino-acids by means of transamination is well known to be a widespread process. Roine ${ }^{5}$ discovered an active transamination procesis in Torula utilis, and Bigger-Gehring6 in $S$. cerevisiae. Transaminase activity was observed only in those cases when $\alpha$-ketoglutaric or glutamic acid was one of the reaction components. Cohen 7 , however, discovered transaminase activity in brewer's yeast for a system consisting of dicarboxylic ac.ds only, whereas in baker's yeast transaminase activity was absent altogether. Braunstein 8 also failed to detect transamination in yeast. These negative results may be accounted for by utilization of transamination products in other reactions of high velocity, or by inadequate sensitivity of the analytical methods used. In certain cases, however, other mechanisms for amino-acid biosynthesis, based on reversibility of direct deamination reactions of various types which play a principal rôle in amino-acid metabolism, have to be considered as well. Participation of $\beta$-methylaspartic acid in transamination in animal tissues and in certain micro-organisms was established ir. a number of studies carried out in our Laboratory ${ }^{9}$.

Table 3. Glutamate, aspartate and $\beta$-methylaspartate biosynthesis from corresponding ketoacids

(T)-is-buffer $0.2 \mathrm{M}, \mathrm{pH} 8.03 ; \alpha$-KG ( $\alpha$-ketoglutarate); OA (oxaloacetate); M-OA (methyloxiloacetate); yeast $200 \mathrm{mg}$; substrates 25 umoles each; total volume $1 \mathrm{ml}$; incubation $60 \mathrm{~min}$ )

\begin{tabular}{|c|c|c|c|c|}
\hline \multirow{2}{*}{\multicolumn{2}{|c|}{ Composition of samples }} & \multicolumn{3}{|c|}{ Amino-acid increase per sample (umoles) } \\
\hline & & Aspartate & Glutamate & $\beta-$ Methylaspartate \\
\hline $\begin{array}{l}(1) \\
(2) \\
(3)\end{array}$ & $\begin{array}{l}\text { DL-Glutamate }+ \text { OA } \\
\text { or M.OA } \\
\text { DL-Aspartate }+\alpha-K G \\
\text { or M.OA } \\
\text { DL-threo- } \beta \text {-Methylaspartate } \\
-\mathrm{O} A \text { or } \alpha-\mathrm{KG}\end{array}$ & $\begin{array}{l}5 \cdot 60 ; 5 \cdot 40 \\
5 \cdot 50 \\
\quad- \\
3 \cdot 96 ; 4 \cdot 07 \\
4 \cdot 17\end{array}$ & $\begin{array}{l}\quad- \\
7 \cdot 24 ; 8 \cdot 20 \\
8 \cdot 09 \\
6 \cdot 42 ; 6 \cdot 71 \\
6 \cdot(04\end{array}$ & $\begin{array}{l}4.92 ; 5 \cdot 07 ; 5 \cdot 11 \\
3.49 ; 3.28 ; \\
3.72\end{array}$ \\
\hline
\end{tabular}

In view of these data it was interesting to study the possibility of biosynthesis of glutamic, aspartic and $\beta$-methylaspartic acids from the corresponding $\alpha$-ketoacids by means of transamination in a disintegrated suspension of $S$. cerevisiae. As follows from the data given in Table 3, obtained by Galegov in our Laboratory, the transamination reaction leading to 


\section{S. R. MARDASHEV}

aspartic, glutamic and $\beta$-methylaspartic acids biosynthesis from the corresponding $\alpha$-ketoacids is rather active in $S$. cerevisiae. Glutamate biosynthesis was found to be the fastest. In general, however, the velocities of biosynthesis of the three amino-acids mentioned are approximately of the same order.

\section{ASPARAGINE AND GLUTAMINE BIOSYNTHESIS AND SOME OF THEIR METABOLIC TRANSFORMATIONS}

\section{Asparagine}

Asparaginase-Asparaginase (L-asparagine-amidohydrolase), catalysing hydrolysis of asparagine to ammonia and aspartate, is a common constituent of living organisms ${ }^{10}$. An extensive study of purified asparaginase from brewer's yeast has been carried out by Grassman and Mayr ${ }^{11}$. S. cerevisiae contains a very active asparaginase, yet the rôle of this reaction in nitrogen metabolism by yeast and other living organisms is still obscure.

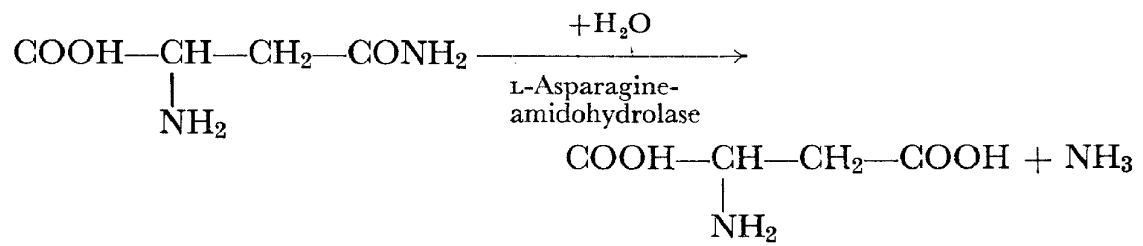

It is well known that enzymatic hydrolysis of L-asparagine is competitively inhibited by D-asparagine. This was demonstrated in Grossowicz's and Halpern's experiments with cell-free extracts of Mycobacterium phle $i^{12}$. It was interesting to study this inhibition mechanism in $S$. cerevisiae. For this purpose Aksenova in our laboratory studied the effect of $D$-asparagine, Daspartic acid, albizziin, carbamylalanine and DL- $\alpha$-methylaspartic acid on the enzymatic hydrolysis of L-asparagine. The results of this research have been summarized in Table 4.

Table 4. Inhibition of asparaginase ( $\mathrm{L}$-asparagine-aminohydrolase)

(Barbital buffer $0.2 \mathrm{M}, \mathrm{pH} 8.4$; yeast extract $0.5 \mathrm{ml} ; \mathrm{L}-\mathrm{Asp}-\mathrm{NH}_{2}$ (L-asparagine) 20 umoles; D-Asp- $\mathrm{NH}_{2}$ (D-asparagine), D-Asp (D-aspartic acid); L-Asp (L-aspartic acid), Albizziin (Alb), C-Ala (carbamyl-L- $\alpha$-alanine), $\mathrm{CH}_{3}$-Asp (DL- $\alpha$-methylaspartic acid) $40 \mu$ moles each; total volume $1 \mathrm{ml}$ )

\begin{tabular}{|c|c|c|c|}
\hline Inhibitor & $\begin{array}{l}\text { Inhibitor: substrate } \\
\text { ratio }\end{array}$ & $\begin{array}{c}\mathrm{NH}_{3} \text { formed } \\
(\mu \text { moles })\end{array}$ & $\begin{array}{l}\text { Per cent of } \\
\text { inhibition }\end{array}$ \\
\hline $\begin{array}{l}\text { D-Asp- } \mathrm{NH}_{2} \\
\text { D-Asp } \\
\text { L-Asp } \\
\text { Alb } \\
\text { C-Ala } \\
\text { CH }_{3} \text {-Asp }\end{array}$ & $\begin{array}{l}2: 1 \\
2: 1 \\
2: 1 \\
2: 1 \\
2: 1 \\
2: 1 \\
--\end{array}$ & $\begin{array}{l}0 \cdot 29 \\
0 \cdot 70 \\
0 \cdot 65 \\
0.72 \\
0 \cdot 72 \\
0 \cdot 29 \\
0 \cdot 74\end{array}$ & $\begin{array}{r}60 \\
7 \\
12 \\
3 \\
3 \\
60 \\
0\end{array}$ \\
\hline
\end{tabular}

D-Asparagine markedly inhibits asparaginase of $S$. cerevisiae (Table 4 ). The marked inhibitory effect of $\alpha$-methylaspartic acid, while D-aspartic and L-aspartic acids do not cause any significant inhibition, is somewhat unexpected. The inhibitory effect of $\mathrm{D}$-asparagine observed may be explained 


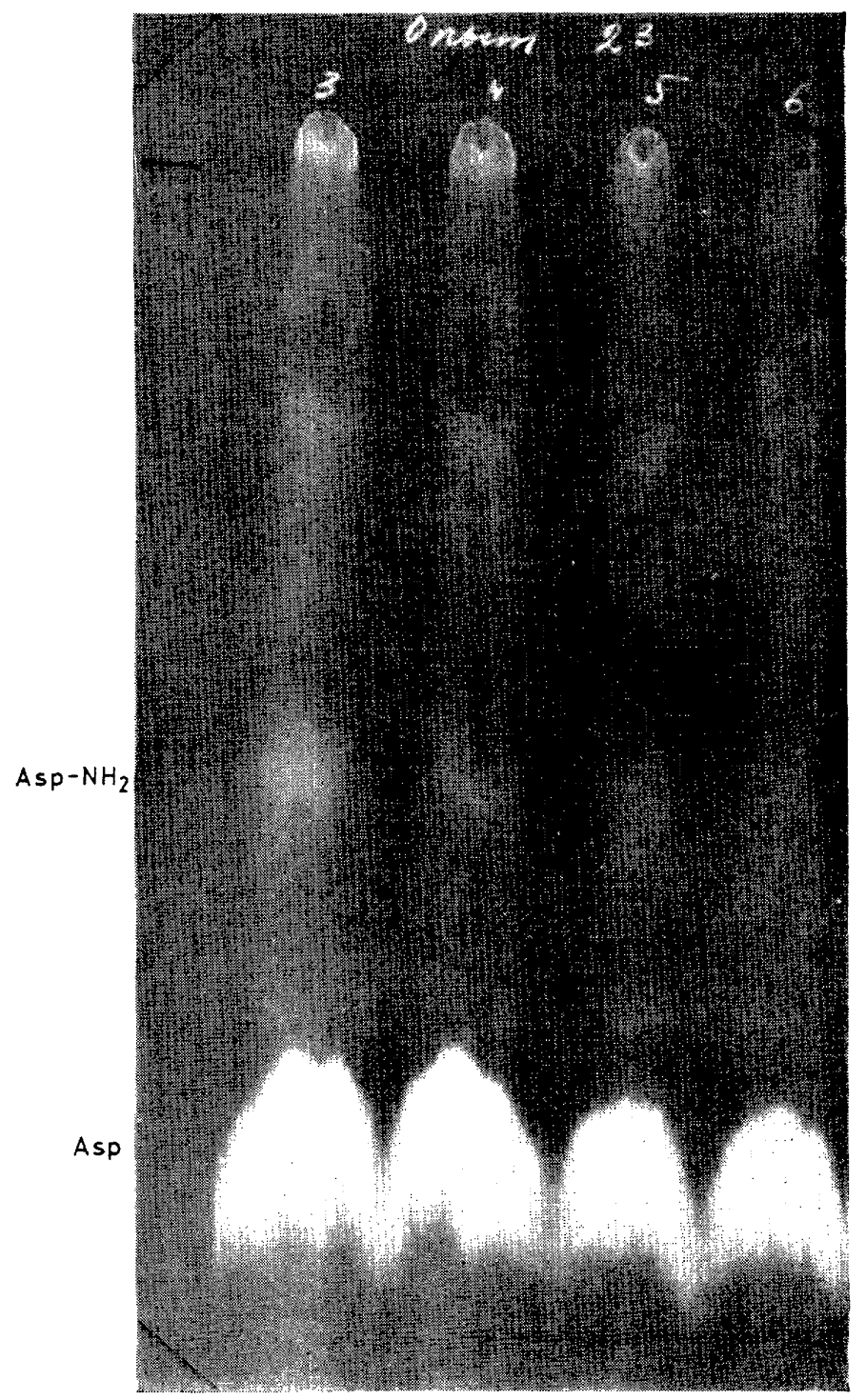

Figure 1. Asparagine biosynthesis from $4-{ }^{14} \mathrm{C}$ aspartic acid; Autoradiochromatogram: (3): $4{ }^{14} \mathrm{C}$-aspartate + $\mathrm{NH}_{4} \mathrm{Cl}+\mathrm{MnCl}_{2}+\mathrm{ATP} ;(4): \mathrm{NH}_{4} \mathrm{Cl}$ ommitted; (5): $\mathrm{MnCl}_{2}$ ommitted; (6): ATP ommitted 


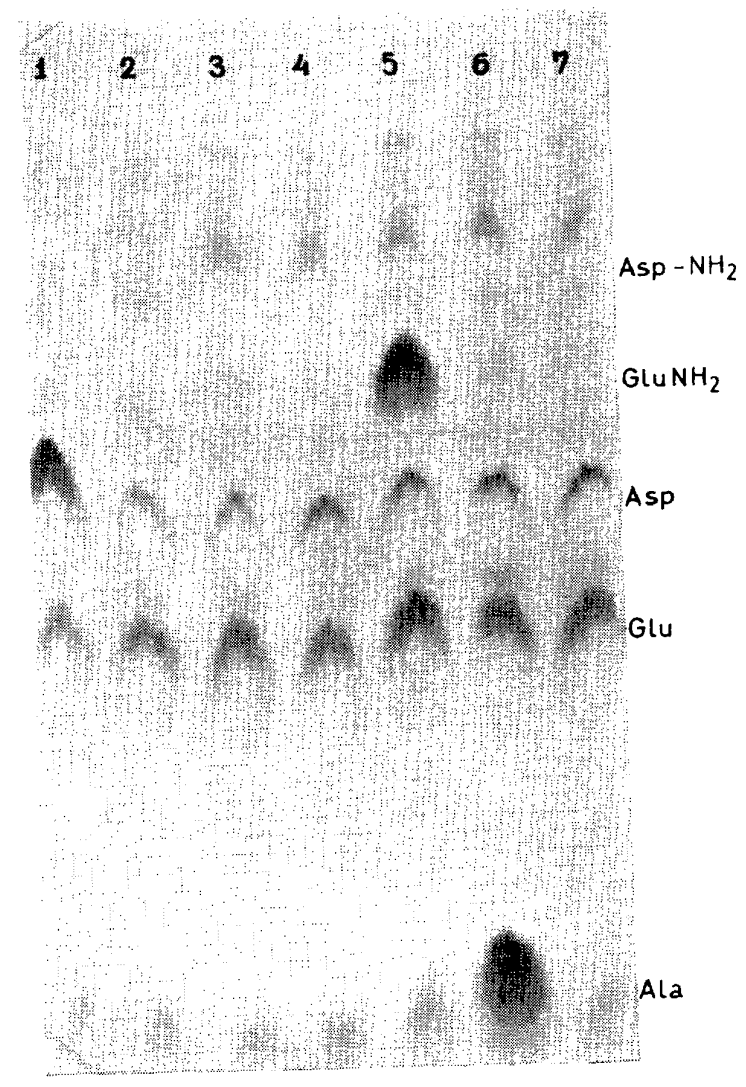

Figure 2. Asparagine biosynthesis from $\alpha$-ketosuccinamic acid $(\alpha-\mathrm{KS})$. Composition of samples-as in Table 5. Chromatogram: butanol-formic acid-water $(75: 15: 10)$. (1): Yeast sact $+\alpha-\mathrm{KS}$ (added after the incubaextract + Asp-NH 2 ; 2 : Yeast extract $+\alpha-\mathrm{KS} ;(5)$ : Yeast extract $+\alpha-\mathrm{KS}+\mathrm{Glu}-\mathrm{NH}_{2}$;

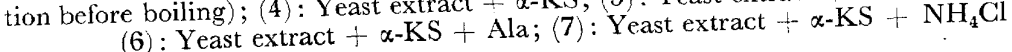




\section{METABOLISM OF DICARBOXYLIC AMINO-ACIDS AND THEIR AMIDES}

by the structural similarity between inhibitor and substrate and may be competitive $^{12}$; the mechanism of $\alpha$-methylaspartic acid inhibitory effect rernains obscure. The active site of asparaginase may be presumed to contain three points of contact corresponding to the $\alpha$-carboxyl, $\alpha$-amino group and $\beta$-amide group ( $\beta$-carboxyl) of asparagine. The interaction of the enzyme with $\alpha$-methylaspartic acid amino group possibly leads to the formation of a more stable association than is the case in the interaction with the substrate. Geometrical relationships at the $\alpha$-carbon atom of the inhibitor and the corresponding region of the active site of asparaginase, preventing the: inhibitor displacement by excess of substrate, are possibly of importance.

In cultivating $S$. cerevisiae in a synthetic medium containing ammonium salts as a source of nitrogen and saccharose as an organic compound, addition of L-asparagine ( $2 \mathrm{~g}$ per litre of medium) leads to a considerable increase in asparaginase content.

Asparagine biosynthesis - The biological synthesis of dicarboxylic amino-acid amides, as suggested by numerous experiments, can occur in the following two ways:

(a)
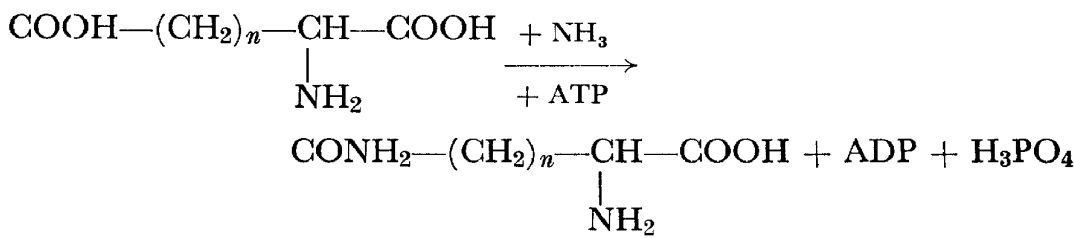

(b)

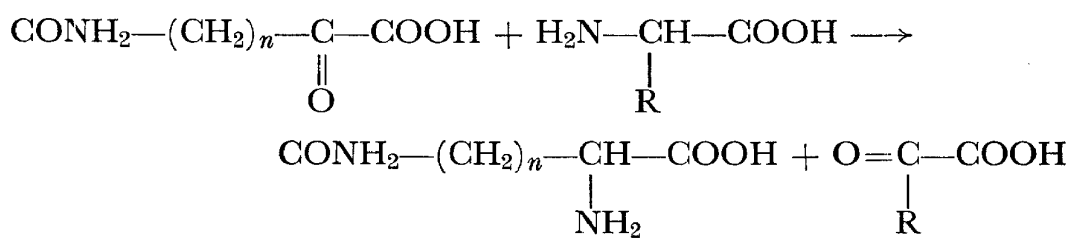

(a) Biosynthesis of asparagine in intact living organisms loaded with aspartic acid and ammonium salts proceeds very intensively and is easily de":ected in experiments with labelled compounds ${ }^{13-16}$. Still the mechanism of this process and its intermediate steps remain quite obscure. Experiments with homogenates, cell-free extracts and purified enzymatic preparations of various animal tissues and micro-organisms have still failed to provide unequivocal evidence for direct amidation of aspartic acid despite the presence of various cofactors and high-energy compounds of the ATP type, in concentrations ensuring glutamine synthesis under similar conditions, For plant tissue extracts such evidence is available; the intensity of synthesis, however, is not significant in these experiments, and the net synthesis has not beerı established ${ }^{16}$.

'The formation of $\beta$-aspartylhydroxamate from aspartic acid and hydroxylamine may be considered, to a certain extent, as a prototype for the asparagine synthesis reaction. Black and Gray ${ }^{17}$ have proved that the enzyme in yeast calalysing asparatylphosphate formation, i.e. aspartate + ATP $\rightarrow$ aspartylphosphate + ADP, also catalyses the formation of aspartylhydroxamate:

Aspartate $+\mathrm{NH}_{2} \mathrm{OH}+\mathrm{ATP} \rightleftharpoons \beta$-Aspartylhydroxamate $+\mathrm{ADP}+\mathrm{H}_{3} \mathrm{PO}_{4}$. 


\section{S. R. MARDASHEV}

In view of this consideration, a study of asparagine biosynthesis in $S$. cerevisiae cell-free extracts was undertaken by Lerman and Aksenova in our laboratory. The samples contained yeast extract, 20 umoles of aspartate, $20 \mu$ moles of ammonium chloride and $10 \mu$ moles of ATP and $\mathrm{MnCl}_{2}$ respectively; after two hours of incubation paper chromatography was carried out. By comparing the colour intensity in spots in the asparagine position in experimental and control chromatograms it proved to be impossible to detect any asparagine synthesis.

In this connection additional experiments with aspartic $4-14 \mathrm{C}$ acid were carried out according to the schemes shown in Table 5.

Table 5. The schemes of experiments on asparagine biosynthesis from aspartic ${ }^{4-14} \mathrm{C}$ acid

\begin{tabular}{|c|c|c|c|c|c|c|c|}
\hline \multirow{2}{*}{ Added components } & \multirow{2}{*}{ umoles per sample } & \multicolumn{6}{|c|}{ Sample numbers } \\
\hline & & 1 & 2 & 3 & 4 & 5 & 6 \\
\hline $\begin{array}{l}\text { Aspartic } 4-{ }^{14} \mathrm{C} \text { acid } \\
\mathrm{NH}_{4} \mathrm{Cl} \\
\mathrm{MnCl}_{2} \\
\text { ATP } \\
\alpha-K e t o \text { succinamic acid } \dagger \\
\text { Yeast extract } \\
\text { Barbital buffer, pH } 8.4\end{array}$ & $\begin{array}{c}20 \\
20 \\
10 \\
10 \\
30 \\
0 \cdot 5 \mathrm{ml}\end{array}$ & $\begin{array}{l}- \\
- \\
- \\
+\end{array}$ & $\begin{array}{l}\bar{z} \\
\bar{z} \\
\overline{+} \\
+\end{array}$ & $\begin{array}{l}+ \\
+ \\
+ \\
+ \\
+ \\
+\end{array}$ & $\begin{array}{l}+ \\
\\
+ \\
+ \\
+ \\
+\end{array}$ & $\begin{array}{l}+ \\
+ \\
+ \\
+ \\
+\end{array}$ & $\begin{array}{l}+ \\
+ \\
+ \\
+ \\
+ \\
+\end{array}$ \\
\hline
\end{tabular}

$\dagger \alpha$-Ketosuccinamic acid addition after incubation facilitates asparagine chromatographic separation.

$\ddagger$ Presence of compound is denoted by + , and its absence by - .

After incubation for $\mathbf{1 . 5}$ hours and the usual treatment of samples, paper chromatography was performed and an autoradiochromatogram produced on an X-ray film (exposure time 7 days, film Davidox, Fotochemische Werke, Berlin). The autoradiochromatogram (Figure 1) clearly reveals the appearance of a radioactive spot in the region where asparagine is commonly found. The most distinct spot is obtained from sample 3 where a full system is available. The spot from sample 4 is much paler; biosynthesis occurs at the expense of pre-formed ammonia present in yeast extract. In samples 5 and 6 , with either $\mathrm{MnCl}_{2}$ or ATP omitted, synthesis is practically absent. These findings show that biosynthesis of labelled asparagine from labelled aspartic acid has taken place, although the intensity of the synthesis is, in general, quite insignificant. The occurrence of asparagine synthetase ( $L$ aspartate: ammonia-ligase (ADP)) appears, therefore, quite probable. Apparently, favourable conditions for this reaction have not yet been adequately clarified. These experiments, however, do not enable the mechanism of biosynthesis to be deciphered with adequate accuracy.

(b) The second pathway for asparagine biosynthesis was discovered by Meister ${ }^{13}$. Somewhat earlier the discovery of the active rôle played by asparagine and glutamine in transamination reactions was made simultaneously in our laboratory, in experiments with glyoxylic acid18, and in Meister's laboratory in experiments with ketoacids ${ }^{19}$. It was found in our laboratory that asparagine and glutamine were more active in transamination with glyoxylic acid than the corresponding amino-acids ${ }^{18}$. The deciphering of the mechanism of this type of transamination by Meister has 
pes:mitted a schematic representation of asparagine transformation in the following way:

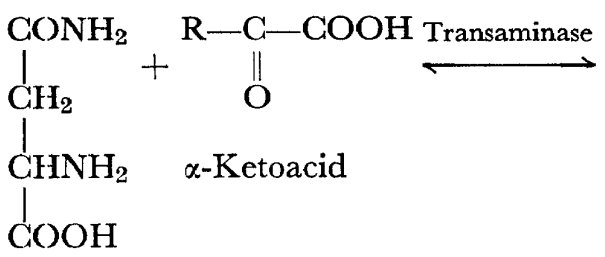

Asparagine

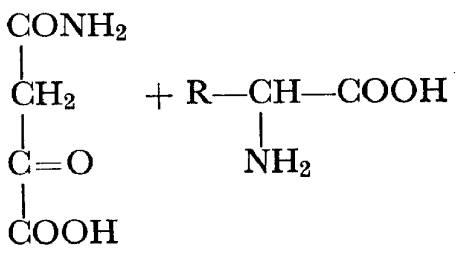

$\alpha$-Ketosuccinamic $\alpha$-Amino-acid acid

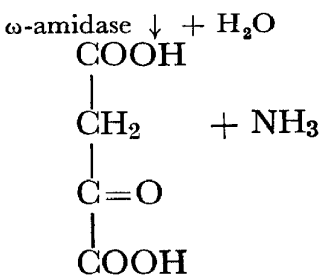

Contrary to the glutamine transaminase reaction, the transaminase reaction of asparagine is practically reversible, since the affinity of the $\omega$-amidase system for $\alpha$-ketosuccinamic acid is not high, and therefore in this case it is possible to demonstrate the reversibility of the transamination reaction, i.e. the formation of asparagine from $\alpha$-ketosuccinamic acid and $L$ - $\alpha$-amino acids $^{13}$.

Lerman and Aksenova in our laboratory studied the biosynthesis of asparagine from $\alpha$-ketosuccinamic acid in yeast. Enzymatic extract of $S$. cerevisiae was incubated with $\alpha$-ketosuccinamic acid and the corresponding donor of the $\alpha$-amino group. Table 6 and Figure 2 illustrate the results of these experiments. The largest asparagine increase is noted in sample 5,

Table 6. Asparagine biosynthesis from ketosuccinamic acid

(Barbital buffer, $0.05 \mathrm{M}, \mathrm{pH} 8.4$; yeast extract (YE) $0.7 \mathrm{ml}$; L- $\alpha$-alanine (Ala), L-glutamine $\left(\mathrm{G}\right.$. $\left.\mathrm{u}-\mathrm{NH}_{2}\right) 20 \mu$ moles each; $\alpha$-ketosuccinamic acid $\left(\alpha\right.$-KS) $60 \mu$ moles; $\mathrm{NH}_{4} \mathrm{Cl} 10 \mu$ moles; incubation for 2 hours at $37^{\circ}$ )

\begin{tabular}{|c|c|c|c|c|c|c|}
\hline \multirow{3}{*}{$\begin{array}{c}\text { Numbers } \\
\text { of } \\
\text { experiments }\end{array}$} & \multicolumn{6}{|c|}{ Asparagine per sample ( $\mu$ moles) } \\
\hline & 2 & 3 & 4 & 5 & 6 & 7 \\
\hline & YE & $\begin{array}{c}\mathrm{YE} \\
+ \\
\alpha-\mathrm{KS} \dagger\end{array}$ & $\begin{array}{c}\mathrm{YE} \\
+ \\
\alpha-\mathrm{K} S\end{array}$ & $\begin{array}{c}\mathrm{YE} \\
+ \\
\alpha-\mathrm{KS} \\
+ \\
\text { Glu-NH} \\
\end{array}$ & $\begin{array}{c}\mathrm{YE} \\
+ \\
\alpha-\mathrm{KS} \\
+ \\
\mathrm{Ala}\end{array}$ & $\begin{array}{c}\mathrm{YE} \\
+ \\
\alpha-\mathrm{KS} \\
+ \\
\mathrm{NH}_{4} \mathrm{Cl} \\
\end{array}$ \\
\hline 15 & 1.45 & 1.69 & 1.69 & $2 \cdot 90$ & $2 \cdot 17$ & $2 \cdot 42$ \\
\hline 16 & 0.96 & $0 \cdot 48$ & 1.45 & $2 \cdot 90$ & 1.93 & 1.93 \\
\hline 17 & 0.96 & $1 \cdot 45$ & $1 \cdot 93$ & $3 \cdot 39$ & $3 \cdot 14$ & $3 \cdot 14$ \\
\hline
\end{tabular}

$\dagger \alpha$-KS arided after the incubation. 
where glutamine serves as the amino group donor. The intensity of asparagine biosynthesis reached 5 per cent with regard to ketosuccinamic acid or 15 per cent with regard to the added amino group donors. The increment of asparagine in other samples $(4,6,7)$ is accompanied, as is seen in Figure 2, by a parallel decrease of endogenous glutamine. Asparagine biosynthesis from ketosuccinamic acid in $S$. cerevisiae strain used by us is catalysed by glutamine transaminase. Participation of asparagine transaminase in this process is also possible ( $c f$. samples $4,6,7$ ).

It should be emphasized, however, that the biosynthesis of asparagine from ketosuccinamic acid will acquire a physiological significance only if the existence of another pathway for $\alpha$-ketosuccinamic acid formation, distinct from the transamination reaction with asparagine participation, is proved. The pathway generally considered at present does not actually lead to a net synthesis of asparagine.

The biosynthesis of asparagine from $\beta$-cyano-L-alanine reported by Ratzkin and Ressler ${ }^{32}$ in Neurospora crassa and seedlings of L. sylvestris W., $L$. odoratus and $V$. villosa have not to be considered as an important pathway for biological formation of asparagine in living organisms.

Sokovnina in our laboratory studied the aspartylhydroxamic acid synthesis from aspartate and hydroxylamine. The results obtained (Table 7)

Table 7. Biosynthesis of $\beta$-aspartylhydroxamic acid from aspartic acid and hydroxylamine

(Acetate buffer 0.2 M, pH 5.9; L-aspartate $260 \mu$ moles; hydroxylamine $1000 \mu$ moles; ATP 26 $\mu$ moles; $\mathrm{MgSO}_{4} 45 \mu$ moles; yeast homogenate $0.5 \mathrm{ml}$; total volume $4.5 \mathrm{ml}$; incubation for $90 \mathrm{~min}$ at $37^{\circ}$ )

\begin{tabular}{c|c|c}
\hline \multicolumn{2}{|c}{$\beta$-Aspartylhydroxamic acid ( $\mu$ moles per sample) } \\
\hline Whole system & Aspartate omitted & Increase \\
\hline 1.3 & 0.95 & 0.35 \\
1.3 & 0.95 & 0.35 \\
1.2 & 0.95 & 0.25 \\
\hline
\end{tabular}

Table 8 . Biosynthesis of $\beta$-aspartylhydroxamic acid from asparagine and hydroxylamine

(Acetate buffer $0.2 \mathrm{M}, \mathrm{pH} 5.9$; L-asparagine $75 \mu$ moles; hydroxylamine $50 \mu$ moles; yeast homogenate $0.5 \mathrm{ml}$; total volume $2 \mathrm{ml}$; incubation for $90 \mathrm{~min}$ at $37^{\circ}$ )

\begin{tabular}{c|c|c|}
\hline \multicolumn{2}{|c|}{ Aspartylhydroxamic acid (umoles per sample) } \\
\hline Whole system & L-Asp- $\mathrm{NH}_{2}$ omitted & Increase \\
\hline $3 \cdot 00$ & $2 \cdot 12$ & $0 \cdot 88$ \\
$3 \cdot 06$ & $2 \cdot 12$ & $0 \cdot 94$ \\
$2 \cdot 98$ & $2 \cdot 12$ & 0.86 \\
$3 \cdot 30$ & $2 \cdot 60$ & $0 \cdot 70$ \\
\hline
\end{tabular}

indicate that, under the experimental conditions used, a distinct aspartylhydroxamic acid tornation is observed. However, the extent of aspartylhydroxamic acid biosynthesis is not large, despite the considerable concentration of reacting substrates.

Some additional data concerning aspartylhydroxamic acid synthesis from asparagine and hydroxylamine were obtained by Sokovnina (Table 8 ). It 


\section{METAJ3OLISM OF DICARBOXYLIC AMINO-ACIDS AND THEIR AMIDES}

follows from these data that $S$. cerevisiae possesses a transferase which is active enough to catalyse the aspartylhydroxamic acid synthesis from L-asparagine and hydroxylamine.

\section{Glutamine}

Glutaminase (L-glutamine-amidohydrolase)-Enzymatic systems responsible for glutamine deamidation have been discovered in animals, plants and microbes. They catalyse deamidation via two pathways operating by different mechanisms ${ }^{13}$.

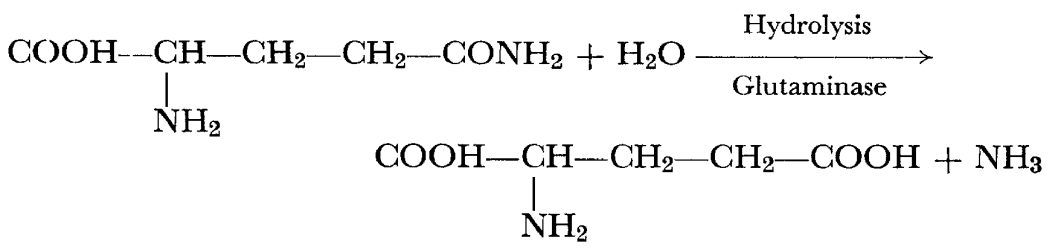<smiles>[R]C(=O)C(=O)CCC(N)C(=O)O</smiles><smiles>[R]C(N)C(=O)O</smiles>

The second pathway connected with transamination will not be discussed here.

Glutaminase has been discovered in many micro-organisms, but it has not been subjected to detailed studies in yeast ${ }^{20}$. Sokovnina studied the glutaminase activity in various strains of Saccharomyces. The glutaminase activity of extracts or homogenates was determined by Conway's method or

Table 9. Glutaminase activity of various Saccharomyces strains (Glutamine 10 umoles; tris buffer $0.2 \mathrm{M}, \mathrm{pH} 7.5$; enzyme $0.5 \mathrm{ml}$; total volume $2.5 \mathrm{ml}$; incubation for 3 hours at room temperature)

\begin{tabular}{|c|c|c|}
\hline \multirow{2}{*}{$\begin{array}{l}\text { Numbers } \\
\text { of strains }\end{array}$} & \multicolumn{2}{|c|}{ Glutaminase activity } \\
\hline & $\mathrm{N}-\mathrm{NH}_{3}$ (in $\mathrm{mg}$ ) & Glutamine ( $\mu$ moles) \\
\hline $\begin{array}{l}\text { S. cerevisiae } 4 \\
\text { S. cerevisiae } 46 \\
\text { S. vini } 169\end{array}$ & $\begin{array}{l}0.033 \\
0 \cdot 040 \\
0.018\end{array}$ & $\begin{array}{l}0.22 \\
0 \cdot 27 \\
0 \cdot 12\end{array}$ \\
\hline
\end{tabular}

by means of paper chromatography. The results obtained are presented in Table 9. It is seen that glutaminase activity is slight (not more than 3 per cent of the substrate added was attached during three hours) and of the 


\section{S. R. MARDASHEV}

same order for various strains of Saccharomyces. The most active extracts with a specific activity $\left(10^{-3} \mathrm{mg} \mathrm{N}-\mathrm{NH}_{3} / \mathrm{mg}\right.$ of protein/h) of about 4 , are produced when the yeast is subjected to a preliminary autolysis for three days. The extracts of glutaminase can be concentrated three- or four-fold, using poly(ethyleneglycol) following Kohn's method ${ }^{21}$.

Investigating the glutaminase activity in Mycobacterium n.sp. we have found that albizziin is a powerful glutaminase inhibitor. Albizziin was isolated from seed of Albizzia julibrissin and of other plants of the Mimosaceae genus by $\mathrm{Gmelin}$ and his associates ${ }^{22}$. Albizziin ( $\alpha$-amino- $\beta$-ureidopropionic acid) can be considered as a peculiar structural analogue of glutamine:<smiles>NC(=O)CCC(N)C(=O)O</smiles>

Glutamine

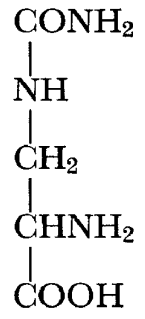

Albizziin

The inhibitory effect found in experiments with glutaminase extracts from Mycobacterium n.sp. is demonstrated in Table 10.

Table 10. Effect of albizziine on glutaminase activity in Mycobacterium n.sp.

(Extract of Mycobacterium n.sp. phosphate buffer $0.06 \mathrm{M}, \mathrm{pH} 6.5$; incubation at $37^{\circ}$; $\mathrm{Glu}-\mathrm{NH}_{2^{-}}$ glutamine; Glu-glutamate)

\begin{tabular}{|c|c|c|c|c|c|c|c|c|}
\hline \multirow{4}{*}{$\begin{array}{c}\text { Time } \\
\text { of incubation } \\
\text { (min) }\end{array}$} & \multirow{2}{*}{\multicolumn{2}{|c|}{$\begin{array}{c}\text { Control } \\
\text { (albizziine } \\
\text { ommitted) }\end{array}$}} & \multicolumn{6}{|c|}{ Albizziine/substrate ratio } \\
\hline & & & \multicolumn{2}{|c|}{$0 \cdot 01: 1$} & \multicolumn{2}{|c|}{$0 \cdot 1: 1$} & \multicolumn{2}{|c|}{$1: 1$} \\
\hline & \multicolumn{8}{|c|}{ Found $(\%)$} \\
\hline & $\begin{array}{l}\text { Glu- } \\
\mathrm{NH}_{2}\end{array}$ & Glu & $\begin{array}{l}\text { Glu- } \\
\mathrm{NH}_{2}\end{array}$ & Glu & $\begin{array}{l}\text { Glu- } \\
\mathrm{NH}_{2}\end{array}$ & Glu & $\begin{array}{l}\text { Glu- } \\
\mathrm{NH}_{2}\end{array}$ & Glu \\
\hline 15 & 79 & 21 & 92 & 8 & 100 & 0 & 100 & 0 \\
\hline $\begin{array}{l}30 \\
60\end{array}$ & $\begin{array}{l}57 \\
41\end{array}$ & $\begin{array}{l}43 \\
60\end{array}$ & $\begin{array}{l}89 \\
84\end{array}$ & $\begin{array}{l}11 \\
16\end{array}$ & $\begin{array}{l}95 \\
92\end{array}$ & $\begin{array}{l}5 \\
8\end{array}$ & $\begin{array}{l}100 \\
100\end{array}$ & $\begin{array}{l}0 \\
0\end{array}$ \\
\hline & & & & & & & & \\
\hline
\end{tabular}

Preliminary data on the dependence of reaction rate on the inhibitor concentration have shown that a mixed type of inhibition apparently occurs.

Sokovnina studied the effect of albizziin, D-glutamate, L-glutamate and D-glutamine on the hydrolytic deamidation of L-glutamine by the Lglutamine-amidohydrolase in $S$. cerevisiae. The data obtained are summarized in Table 11. It is obvious that albizziin exerts an inhibitory effect on yeast glutaminase. This effect, however, is considerably less than that observed in experiments with Mycobacterium n.sp. glutaminase (Table 10). Apparently, yeast and bacteria glutaminases have somewhat different 


\section{METABOLISM OF DIGARBOXYLIC AMINO-AGIDS AND THEIR AMIDES}

properties. Noteworthy is the fact that D-glutamine has no effect at all $\uparrow$, whereas D-glutamic acid and L-glutamic acid produce a distinct inhibitory action. According to $\mathrm{Krebs}^{23}$, L-glutamic and $\mathrm{D}$-glutamic acids almost completely suppress glutaminase activity in a pig kidney extract. At the same time aspartic acid has no effect on asparaginase. These results are in complete accordance with the data obtained in our experiments on yeast (Tables 4 and 11 ).

Table 11. Glutaminase inhibition

(Tris bufler $0.2 \mathrm{~m} \mathrm{pH} \mathrm{7.5;} \mathrm{L-Glu-} \mathrm{NH}_{2}$ and inhibitor $10 \mu$ moles each; $0.5 \mathrm{ml}$ of concentrated ye:zst extract; total volume $2.5 \mathrm{ml}$; incubation for 1, 2, 3 hours at room temperature)

\begin{tabular}{l|c|c|c|c}
\hline \multicolumn{1}{c|}{ Inhibitor } & $\begin{array}{c}\text { L-Glu-NH } \\
\text { inhibitor } \\
\text { ratio }\end{array}$ & \multicolumn{3}{|c}{ Inhibition $(\%)$} \\
\hline Albizziin & $1: 1$ & 13 & 19 & 33 \\
D-Glutamate & $1: 1$ & 19 & $\mathbf{4 3}$ & 55 \\
L-Glutamate & $1: 1$ & 10 & 27 & 40 \\
D-Glutamine & $1: 1$ & 0 & 0 & 0 \\
\hline
\end{tabular}

Glutamine biosynthesis-The pathway of glutamine biosynthesis from glutamic acid and ammonia has been well substantiated experimentally:

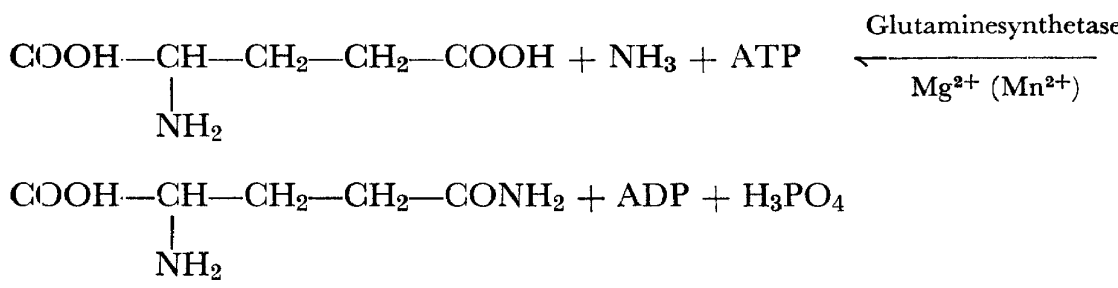

Table 12. Glutamine biosynthesis from glutamic acid and ammonia ( $\mu$ moles per sample)

$\left\langle 0.5 \mathrm{ml}\right.$ of yeast homogenate; glutamate $267 \mu$ moles; $\mathrm{NH}_{4} \mathrm{Cl} 32.4 \mu$ moles; ATP $13 \mu$ moles; $\mathrm{MgSO}_{4} 5 \mu$ moles; acetate buffer $0.2 \mathrm{M}$; $\mathrm{pH} 5.9$; incubation for $90 \mathrm{~min}$ at $37^{\circ}$ )

\begin{tabular}{c|c|c|c}
$\begin{array}{c}\text { Numbers of } \\
\text { experiments }\end{array}$ & $\begin{array}{c}\text { Whole } \\
\text { system }\end{array}$ & $\begin{array}{c}\text { Glutamate } \\
\text { ommitted }\end{array}$ & $\begin{array}{c}\text { Increase } \\
(\mu \mathrm{moles})\end{array}$ \\
\hline $1+$ & 1.97 & 0.81 & 1.16 \\
$2+$ & 1.87 & 0.81 & 1.08 \\
3 & 1.59 & 0.94 & 0.65 \\
4 & 1.48 & 0.94 & 0.54 \\
5 & 1.49 & 0.94 & 0.55 \\
\hline
\end{tabular}

$\ddagger$ Homogenate was dialysed at $0^{\circ}$ against distilled water for 20 hours.

This reaction, discovered in tissues of animals, plants and micro-organisms ${ }^{13}$, was studied by Sokovnina in S. cerevisiaie. The results presented in Table 12 show that $S$. cerevisiae have an enzymatic system (glutamine synthetase, i.e.

† However, this effect was explained much more simply when we had checked the Dglutamine received from Gee Lawson Chemicals Ltd. "Foreign" which was used by us in our experiments. The trade mark " $D$-glutamine" proved not to be correct as this preparation is ratural glutamine i.e. L-glutamine, and not D-glutamine. 


\section{S. R. MARDASHEV}

L-glutamate: ammonia-ligase (ADP)) catalysing glutamine biosynthesis from glutamic acid and ammonia, even though this process occurs with comparatively low intensity. The possibility of enzymatic hydrolysis of glutamine formed does not introduce any substantial correction owing to the weak glutamine-amidohydrolase activity of yeast.

Experiments on $\gamma$-glutamylhydroxamic acid biosynthesis were undertaken for additional verification of possible glutamine biosynthesis from glutamic acid and ammonia. Glutamylhydroxamic acid formation was determined according to Lipmann and Tuttle ${ }^{24}$. The results of this research indicate that $\gamma$-glutamylhydroxamic acid biosynthesis takes place in yeast (Table 13). However, approximately 0.5 per cent of glutamate added was utilized in the reaction. These experiments in model systems confirm the presence of a glutamine-synthetase system in $S$. cerevisiae and its relatively slight activity.

Table 13. Biosynthesis of $\gamma$-glutamylhydroxamic acid (in $\mu$ moles per sample) (260 $\mu$ moles of glutamate; $1000 \mu$ moles of hydroxylamine; $13 \mu$ moles of ATP; $45 \mu$ moles $\mathrm{MgSO}_{4}$; acetate buffer $0.2 \mathrm{M} \mathrm{pH} 5.9$; yeast homogenate or extract $0.5 \mathrm{ml}$ per sample)

\begin{tabular}{c|c|c|c}
\hline $\begin{array}{c}\text { Whole } \\
\text { system }\end{array}$ & $\begin{array}{c}\text { Glutamate } \\
\text { ommitted }\end{array}$ & $\begin{array}{c}\text { Hydroxylamine } \\
\text { ommitted }\end{array}$ & Increase \\
\hline $3.00 \dagger$ & 1.68 & - & 1.32 \\
$3.00 \dagger$ & 1.68 & - & 1.32 \\
$3.60 \dagger$ & 1.68 & - & 1.92 \\
$3.10 \dagger$ & 1.80 & - & 1.30 \\
$3.05 \dagger$ & 1.61 & 1.44 \\
$2.78 \dagger$ & 1.55 & 0.98 & 1.23 \\
$1.97 \ddagger$ & $(1.20)$ & 0.48 & $0.99(0.77)$ \\
$1.90 \ddagger$ & $(1.27)$ & $1.42(0.63)$ \\
\hline
\end{tabular}

† Incubation for $90 \mathrm{~min}$; yeast homogenate.

+ Incubation for $60 \mathrm{~min}$; yeast extract.

It should be added that it is also possible to detect in $S$. cerevisiae the following transferase reaction, as a result of which ammonia is released from the amide group of glutamine:

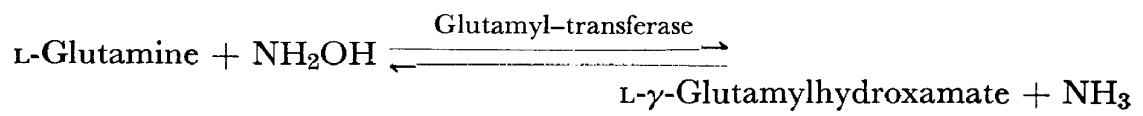

The data obtained on this subject by Sokovnina and presented in Table 14 form the basis for a conclusion on the presence in yeast of this type of transferase reaction, which, however, occurs at a low rate (about 1 per cent of substrate is attacked during 1-1.5 hours).

Whether the reactions of synthesis and the transfer of the glutamine amino group are catalysed by a single enzymatic system still remains obscure. The Proteus vulgaris cell-free extracts synthesize glutamine from glutamic acid and ammonia in the presence of ATP and Mg or Mn ions. Ammonia replacement by hydroxylamine leads to glutamylhydroxamic acid synthesis instead of glutamine. In addition, glutamylhydroxamic acid biosynthesis from glutamine occurs at a faster rate than from glutamic acid; it does not require $\mathrm{Mg}^{2+}$ and $\mathrm{ATP}^{25}$. On the other hand, there is evidence to the effect that the glutamyltransferase reaction in animals and plants requires $\mathrm{Mg}$ or 


\section{METABOLISM OF DICARBOXYLIC AMINO-ACIDS AND THEIR AMIDES}

$\mathrm{Mn}$ ions, as well as catalytic quantities of ADP and inorganic phosphate ${ }^{26}$. Therefore, experiments with enzymatic preparations of high purity are necessary in order to ascertain the properties of $\gamma$-glutamyltransferase systems of various origin.

rable 14. Biosynthesis of $\gamma$-glutamylhydroxamic acid from glutamine and hydroxylamine

$(0.5 \mathrm{ml}$ of homogenate or yeast extract; glutamine 75 umoles; hydroxylamine 50 umoles; tris-buffer $0.2 \mathrm{M} \mathrm{pH} 8.0$; total volume $2 \mathrm{ml}$; incubation for $60-90 \mathrm{~min}$ at $37^{\circ}$ )

\begin{tabular}{|c|c|c|c|c|}
\hline \multirow{2}{*}{ Number of experiments $\dagger$} & \multicolumn{4}{|c|}{$\gamma$-Glutamylhydroxamic acid per sample ( $\mu$ moles) } \\
\hline & $\begin{array}{l}\text { Whole } \\
\text { system }\end{array}$ & $\begin{array}{c}\text { Glu-NH} \\
\text { ommitted }\end{array}$ & $\begin{array}{c}\mathrm{NH}_{2} \mathrm{OH} \\
\text { ommitted }\end{array}$ & Increase \\
\hline $\begin{array}{l}1 \\
2 \\
3 \\
4 \\
5 \\
6 \\
7\end{array}$ & $\begin{array}{l}2 \cdot 10 \\
1 \cdot 90 \\
2 \cdot 14 \\
1 \cdot 90 \\
2 \cdot 80 \\
1 \cdot 98 \\
1 \cdot 48\end{array}$ & 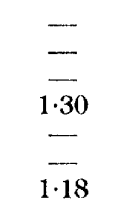 & $\begin{array}{c}1.50 \\
1.50 \\
1.50 \\
- \\
1.90 \\
1.21 \\
-\end{array}$ & $\begin{array}{l}0.60 \\
0.40 \\
0.64 \\
0.60 \\
0.90 \\
0.77 \\
0.30\end{array}$ \\
\hline
\end{tabular}

+ Experiments 1-4: yeast extract; incubation $60 \mathrm{~min}$

Experiments 5-7: yeast homogenate; incubation $90 \mathrm{~min}$.

Table 15. Inhibitory effect of some dicarboxylic acids on $\gamma$-glutamylhydroxamic acid biosynthesis

\begin{tabular}{|c|c|c|c|c|c|}
\hline Inhibitor & $\begin{array}{c}\text { Asp- } \mathrm{NH}_{2} \text { : } \\
\text { inhibitor } \\
\text { ratio }\end{array}$ & $\begin{array}{c}\text { Per cent } \\
\text { of } \\
\text { inhibition }\end{array}$ & Inhibitor & $\begin{array}{l}\text { Asp- } \mathrm{NH}_{2} \text { : } \\
\text { inhibitor } \\
\text { ratio }\end{array}$ & $\begin{array}{c}\text { Per cent } \\
\text { of } \\
\text { inhibition }\end{array}$ \\
\hline $\begin{array}{l}\text { Methylsuccinate } \\
\text { Methylsuccinate } \\
\text { Methylsuccinate }\end{array}$ & $\begin{array}{l}1: 1 \\
1: 3 \\
1: 5\end{array}$ & $\begin{array}{r}0 \\
8 \\
26\end{array}$ & $\begin{array}{l}\alpha \text {-Methylglutarate } \\
\alpha \text {-Methylglutarate } \\
\alpha \text {-Methylglutarate }\end{array}$ & $\begin{array}{l}1: 1 \\
1: 3 \\
1: 5\end{array}$ & $\begin{array}{l}0 \\
0 \\
0\end{array}$ \\
\hline $\begin{array}{l}\text { Citraconate } \\
\text { Citraconate } \\
\text { Citraconate }\end{array}$ & $\begin{array}{l}1: 1 \\
1: 3 \\
1: 5\end{array}$ & $\begin{array}{r}0 \\
15 \\
16\end{array}$ & $\begin{array}{l}\beta \text {-Methylglutarate } \\
\beta \text {-Methylglutarate } \\
\beta \text {-Methylglutarate }\end{array}$ & $\begin{array}{l}1: 1 \\
1: 3 \\
1: 5\end{array}$ & $\begin{array}{l}0 \\
0 \\
0\end{array}$ \\
\hline $\begin{array}{l}\text { Glutaconate } \\
\text { Glutaconate } \\
\text { Glutaconate }\end{array}$ & $\begin{array}{l}1: 1 \\
1: 3 \\
1: 5\end{array}$ & $\begin{array}{r}0 \\
0 \\
10\end{array}$ & $\begin{array}{l}S \text {-Carbamylcysteine } \\
S \text {-Carbamylcysteine } \\
S \text {-Carbamylcysteine }\end{array}$ & $\begin{array}{l}1: 1 \\
1: 9 \\
1: 5\end{array}$ & $\begin{array}{l}10 \\
10 \\
19\end{array}$ \\
\hline $\begin{array}{l}\text { Mesaconate } \\
\text { Mesaconate } \\
\text { Mesaconate }\end{array}$ & $\begin{array}{l}1: 1 \\
1: 3 \\
1: 5\end{array}$ & $\begin{array}{r}8 \\
14 \\
30\end{array}$ & $\begin{array}{l}\text { Adipinate } \\
\text { Adipinate } \\
\text { Adipinate }\end{array}$ & $\begin{array}{l}1: 1 \\
1: 3 \\
1: 5\end{array}$ & $\begin{array}{l}0 \\
0 \\
0\end{array}$ \\
\hline $\begin{array}{l}\text { Itaconate } \\
\text { Itaconate } \\
\text { Itaconate }\end{array}$ & $\begin{array}{l}1: 1 \\
1: 3 \\
1: 5\end{array}$ & $\begin{array}{l}16 \\
17 \\
14\end{array}$ & $\begin{array}{l}\beta \text {-Hydroxyaspartate } \\
\beta \text {-Hydroxyaspartate } \\
\beta \text {-Hydroxyaspartate }\end{array}$ & $\begin{array}{l}1: 1 \\
1: 3 \\
1: 5\end{array}$ & $\begin{array}{l}0 \\
0 \\
0\end{array}$ \\
\hline
\end{tabular}

Table; 15 and 16 present data obtained in our laboratory on inhibition of glutamyltransferase (Table 15) and aspartyltransferase (Table 16) reactions by some: dicarboxylic acids in yeast. Glutamyltransferase activity changes but little under the effect of the substances tested. At the equimolar substrate and inhibitor ratio the inhibitory effect is equal to zero or close to this value. Even in a 1:5 ratio it rarely reaches 30 per cent. 


\section{S. R. MARDASHEV}

An entirely different picture is observed when the effect of the same substances on aspartyltransferase is studied. The inhibitory effect is absent only in two cases (itaconic and adipinic acids). The strength of the inhibitory effect reaches 60 to 80 per cent for some substances. These data prove that glutamyltransferase and aspartyltransferase are different enzymes.

Table 16. Inhibitory effect of some dicarboxylic acids on $\beta$-aspartylhydroxamic acid biosynthesis

\begin{tabular}{|c|c|c|c|c|c|}
\hline Inhibitor & $\begin{array}{c}\text { ASP-NH } \\
\text { inhibitor } \\
\text { ratio }\end{array}$ & $\begin{array}{l}\text { Per cent } \\
\text { of } \\
\text { inhibition }\end{array}$ & Inhibitor & $\begin{array}{c}\text { ASP-NH } \\
\text { inhibitor } \\
\text { ratio }\end{array}$ & $\begin{array}{l}\text { Per cent } \\
\text { of } \\
\text { inhibition }\end{array}$ \\
\hline $\begin{array}{l}\text { Methylsuccinate } \\
\text { Methylsuccinate } \\
\text { Methylsuccinate }\end{array}$ & $\begin{array}{l}1: 1 \\
1: 3 \\
1: 3\end{array}$ & $\begin{array}{l}24 \\
41 \\
47\end{array}$ & $\begin{array}{l}\alpha \text {-Methylglutarate } \\
\alpha \text {-Methylglutarate } \\
\alpha \text {-Methylglutarate }\end{array}$ & $\begin{array}{l}1: 1 \\
1: 3 \\
1: 5\end{array}$ & $\begin{array}{l}22 \\
35 \\
38\end{array}$ \\
\hline $\begin{array}{l}\text { Citraconate } \\
\text { Citraconate } \\
\text { Citraconate }\end{array}$ & $\begin{array}{l}1: 1 \\
1: 3 \\
1: 5\end{array}$ & $\begin{array}{l}29 \\
43 \\
60\end{array}$ & $\begin{array}{l}\beta \text {-Methylglutarate } \\
\beta \text {-Methylglutarate } \\
\beta \text {-Methylglutarate }\end{array}$ & $\begin{array}{l}1: 1 \\
1: 3 \\
1: 5\end{array}$ & $\begin{array}{l}27 \\
38 \\
82\end{array}$ \\
\hline $\begin{array}{l}\text { Glutaconate } \\
\text { Glutaconate } \\
\text { Glutaconate }\end{array}$ & $\begin{array}{l}1: 1 \\
1: 3 \\
1: 5\end{array}$ & $\begin{array}{l}27 \\
32 \\
41\end{array}$ & $\begin{array}{l}S \text {-Carbamylcysteine } \\
S \text {-Carbamylcysteine } \\
S \text {-Carbamylcysteine }\end{array}$ & $\begin{array}{l}1: 1 \\
1: 3 \\
1: 5\end{array}$ & $\begin{array}{l}20 \\
35 \\
43\end{array}$ \\
\hline $\begin{array}{l}\text { Mesaconate } \\
\text { Mesaconate } \\
\text { Mesaconate }\end{array}$ & $\begin{array}{l}1: 1 \\
1: 3 \\
1: 5\end{array}$ & $\begin{array}{l}17 \\
29 \\
50\end{array}$ & $\begin{array}{l}\text { Adipinate } \\
\text { Adipinate } \\
\text { Adipinate }\end{array}$ & $\begin{array}{l}1: 1 \\
1: 3 \\
1: 5\end{array}$ & $\begin{array}{l}0 \\
0 \\
0\end{array}$ \\
\hline $\begin{array}{l}\text { Itaconate } \\
\text { Itaconate } \\
\text { Itaconate }\end{array}$ & $\begin{array}{l}1: 1 \\
1: 3 \\
1: 5\end{array}$ & $\begin{array}{r}0 \\
0 \\
10\end{array}$ & $\begin{array}{l}\beta \text {-Hydroxyaspartate } \\
\beta \text {-Hydroxyaspartate } \\
\beta \text {-Hydroxyaspartate }\end{array}$ & $\begin{array}{l}1: 1 \\
1: 3 \\
1: 5\end{array}$ & $\begin{array}{l}23 \\
25 \\
27\end{array}$ \\
\hline
\end{tabular}

\section{Participation of glutamine in guanine synthesis in yeast}

Transformation of xanthosine-5'-monophosphate into guanosine- $5^{\prime}$-monophosphateIt is known that guanosine-5'-monophosphate synthesis in animal tissues occurs by way of xanthosine-5'-monophosphate amination at the expense of the amide group of glutamine ${ }^{27}$. The following mechanism for this reaction, studied on purified enzyme preparations from the pigeon liver by Lagerkvist $^{28}$, was proposed:

Xanthosine-5'-monophosphate + Glutamine $+\mathrm{ATP}+\mathrm{H}_{2} \mathrm{O} \stackrel{\mathrm{Mg}^{2+}}{\longrightarrow}$ Guanosine-5'-monophosphate + Glutamate + AMP + Pyrophosphate

In experiments with purified enzymatic preparations glutamine cannot be replaced by asparagine or glutamic acid. Ammonia is also used in this system, but its saturating concentration is 200 times that of glutamine and its maximal activity is only 15 per cent of the latter. Apparently, ammonia is not used in this system directly, but only after its transformation into the amide group of glutamine.

The mechanism of action of this enzyme (xanthosine-5'-phosphate: Lglutamine-amidolygase (AMP)) is analogous to that discovered by Abrams and Bentley 29 in mammals (excluding additional sulphydryl compound requirements) and is, apparently, connected with a simultaneous interaction of xanthosine-5'-monophosphate with ATP (electrophilic partner) and with 


\section{METABOLISM OF DICARBOXYLIC AMINO-ACIDS AND THEIR AMIDES}

glutamine (nucleophilic partner) without formation of consecutive intermediary compounds.

Moyed and Magasanik ${ }^{30}$, however, discovered in Aerobacter aerogenes an enzyme [(xanthosine-5'-phosphate: ammonia-ligase (AMP)] catalysing the transformation of xanthosine-phosphate into guanosine phosphate due to anmonia addition:

\section{Xanthosine-5'-monophosphate $+\mathrm{NH}_{3}+\mathrm{ATP}$ \\ Guanosine-5'-monophosphate + AMP + Pyrophosphate}

It was interesting to study the process of guanosine-5'-monophosphate formation in $S$. cerevisiae. The experiments were carried out by Yarovaya with preparations of xanthosine $-5^{\prime}$-monophosphate and deoxyxanthosine-5' monophosphate which we had produced by guanosine-5'-monophosphate and deoxyguanosine-5'-monophosphate deamination. Typical samples were as follows: $2 \mathrm{~g}$ of yeast mass destroyed in a Hughes' press were placed in tris-buffer $\mathrm{pH} 7 \cdot 2$ containing $58 \mu$ moles ATP, $200 \mu$ moles $\mathrm{MgSO}_{4}$. Experimental samples were given an addition of $8.96 \mu$ moles xanthosine monophosphate and $22 \mu$ moles L-glutamine or $22 \mu$ moles $\mathrm{NH}_{4} \mathrm{Cl}$. The control sample contained $22 \mu$ moles L-glutamine and contained no xanthosire monophosphate. The final volume was $8 \mathrm{ml}$. After incubation for 40 minutes at $28^{\circ}$, precipitation and further treatment were carried out, including hydrolysis in perchloric acid, as usual. The guanine formed was isolated on Dowex $50 \times 8$ column and its concentration was determined from optical density measurements on an SF-4 spectrophotometer. It follows from the results of the experiments presented in Table 17 that guanosine

'Table 17. Biosynthesis of guanosine-5'-monophosphate from xanthosine-5'monophosphate

(Tris-bufier 0.05 м pH 7.2; ATP.58 umoles, $\mathrm{MgSO}_{4} 200 \mu$ moles; xanthosine-5'-monophosphate (XMP) 8.96 umoles; L-glutamine (Glu-NH $\left.{ }_{2}\right) 22 \mu$ moles; $\mathrm{NH}_{4} \mathrm{Cl} 22 \mu$ moles; yeast 2 g; total volume $8 \mathrm{ml}$; incubation for $40 \mathrm{~min}$ at $28^{\circ}$ )

\begin{tabular}{|c|c|c|c|c|c|c|c|c|}
\hline \multirow{3}{*}{ Content of samples } & \multicolumn{8}{|c|}{ Guanine formed } \\
\hline & \multicolumn{4}{|c|}{$(\mu g)$} & \multicolumn{4}{|c|}{ Per cent of control } \\
\hline & 1 & 2 & 3 & 4 & 1 & 2 & 3 & 4 \\
\hline $\begin{array}{l}\text { XMP }+ \text { Glu-NH } \\
\text { XMP + } \mathrm{NH}_{4} \mathrm{Cl} \\
\text { Control }\left(\mathrm{Glu}-\mathrm{NH}_{2}\right) \\
\text { Control (XMP) }\end{array}$ & $\begin{array}{c}289 \cdot 6 \\
\overline{171 \cdot 6} \\
-\end{array}$ & $\begin{array}{c}90 \cdot 6 \\
\mathbf{8 5} \cdot 2 \\
\mathbf{5 4} \cdot 0 \\
-\end{array}$ & $\begin{array}{r}103 \cdot 2 \\
65 \cdot 2 \\
54 \cdot 0 \\
-\end{array}$ & $\begin{array}{l}297 \\
112 \cdot 5 \\
\overline{103}\end{array}$ & $\frac{169}{100}$ & $\begin{array}{l}168 \\
158 \\
100 \\
-\end{array}$ & $\begin{array}{l}193 \\
121 \\
100 \\
-\end{array}$ & $\begin{array}{r}287 \\
108 \\
100\end{array}$ \\
\hline
\end{tabular}

phosphate synthesis from xanthosine phosphate at the expense of glutamine occurs in yeast. The small increase of guanosine phosphate in experiments with $\mathrm{NH}_{4} \mathrm{Gl}$, which was observed, was apparently due to ammonia utilization for glutamine biosynthesis from glutamic acid contained in yeast. However, the possibility of direct xanthylic acid amination with ammonia cannot be excluded.

Negative results were obtained in preliminary experiments on deoxanthosine monophosphate amination with glutamine. 


\section{S. R. MARDASHEV}

Effect of albizziin on guanosine-5'-monophosphate synthesis-Considering the inhibitory effect of ablizziin on glutaminase, and taking into account the glutamine participation in guanosine phosphate biosynthesis, as well as the structural similarity between glutamine and albizziin, it was interesting to study the latter's effect on the rate of guanosine monophosphate biosynthesis from xanthosine monophosphate. We have found with an equimolar ratio of abilizziin and glutamine that distinct inhibition of biosynthesis is noted (Tables 18:I, II).

The inhibition, however, is not as significant as in experiments with Mycobacterium n.sp. glutaminase. The small increase (10 and 37 per cent) in control samples, to which only glutamine and albizziin were added, was not considered as important at first. It was decided to increase the albizziin concentration five fold in order to intensify the inhibitory effect. The data obtained are summarized in Table 18 (III, IV). The effect caused by

Table 18. Effect of albizziin on guanine biosynthesis

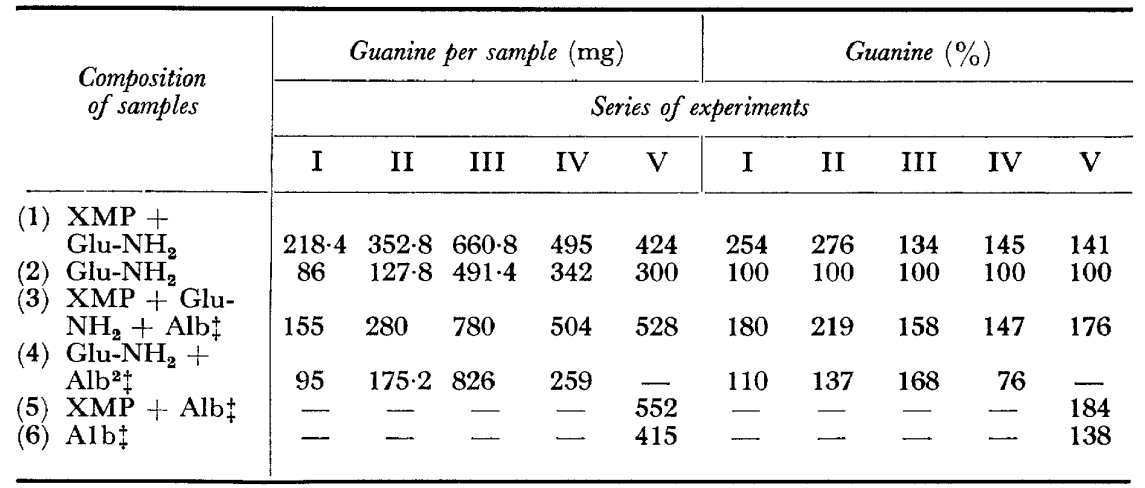

+ Guanine content in samples with glutamine assumed to be 100 .

‡ Glutamine: albizziin ratio in experiments $I$ and II was $1: 1$; in experiments III-V it was $1: 5$.

albizziin in high concentrations was quite unexpected. An activation of the process was found instead of inhibition. This effect proved to be quite reproducible in control samples containing only albizziin and the enzymatic system; an increase of the guanine containing fraction was observed $($ Table $18, \mathrm{~V})$. If the value found in this control sample is considered one

Table 19. Effect of different quantities of albizziin on a value of guanine fraction

\begin{tabular}{|c|c|c|c|c|c|c|c|}
\hline \multicolumn{6}{|c|}{ Content of samples } & \multicolumn{2}{|c|}{ Guanine per sample } \\
\hline \multirow[b]{2}{*}{$\begin{array}{l}\text { Glu- } \\
\mathrm{NH}_{2}\end{array}$} & \multirow{2}{*}{ XMP } & \multirow{2}{*}{$\mathrm{MgSO}_{4}$} & \multirow{2}{*}{ ATP } & \multicolumn{2}{|c|}{ Alb $\dagger$} & \multirow{2}{*}{$(\mathrm{mg})$} & \multirow{2}{*}{$(\%)$} \\
\hline & & & & $1: 5$ & $1: 10$ & & \\
\hline+ & + & + & + & - & - & 420 & 130 \\
\hline- & + & + & + & - & - & 324 & 100 \\
\hline+ & + & + & + & + & - & 462 & 142 \\
\hline+ & + & + & + & - & + & $\mathbf{5 7 6}$ & 178 \\
\hline- & - & + & + & - & + & 456 & 140 \\
\hline
\end{tabular}

$\dagger$ Glutamine: albizziin ratio. 
may conclude that albizziin inhibits the glutamine utilization in the XMP $\rightarrow$ GIMP reaction, but contributes to an increase in the guanine fraction due to another process (Table 19).

It is noteworthy that in all the experiments where albizziin was added a new small peak preceding guanine, appeared on the elution curve (elution with $3 \mathrm{~N} \mathrm{HCl}$ solution). We failed to separate this fraction from guanine completely. It may be supposed that $S$. cerevisiae convert albizziin into a new nitrogenous base according to the following scheme:<smiles>NC(=O)C(N)C(N)C(=O)O</smiles>

Albizziin<smiles>N[C@@H]1CNC(=O)[NH2+]1</smiles>

2,6-Dioxy-5-amino-dihydropyrimidine

It is probable that some other nitrogenous bases are synthesized by means of a non-specific utilization of the albizziin carbamyl group. This problem is now under study at our laboratory.

\section{References}

1 A. Munch-Petersen and H. A. Barker. J. Biol. Chem. 230, 649 (1958).

2 H. A. Barker, R. D. Smith, R. Marilyn Wilson, and H. Weissbach. J. Biol. Chem. 234, 320 1959).

3 E. Adler, V. Hellström, G. Günther, and H. von Euler. Z. physiol. Chem. 255, 14 (1938).

4 E. Adler, G. Günther, and J. E. Everett. Z. Physiol. Chem. 255, 27 (1938).

5 P. Roine. "On the formation of primary amino-acids in the protein synthesis in yeasts", Thesis, Helsinki (1947).

6. Bigger-Gehring. J. Gen. Microbiol. 13, 45 (1955).

7 P. P. Cohen. Symposium on Respiratory Enzymes, p. 210, Univ. Wisconsin Press (1942).

${ }^{8}$ A. E. Braunstein. Biochemistry of the Amino-Acids Metabolism, p. 80, Moscow (1949).

' G. A. Galegov. "The investigations in the field of metabolism and biosynthesis of $\beta$ methylaspartic acid", Thesis, Moscow (1963).

10 A. Ya Nicolayev. Thesis, Moscow (1963).

11 W. Grassmann and O. Mayr. Z. Physiol. Chem. 214, 185 (1933).

12 N. Grossowicz and Y. S. Halpern. Nature 177, 623 (1956).

13 A. Mejster. Biochemistry of the Amino-Acids, Academic Press, New York (1957).

14 J. R. Mardashev. Usp. Sovrem. Biol. 40, 8 (1955).

15 W. L. Kretovich. Biochemistry of Autotrophic Nitrogen Assimilation in Plants, Bach's lecture XVI, Moscow (1961).

16 G. C. Webster and J. E. Varner. J. Biol. Chem. 215, 91 (1955).

17 is. Black and N. M. Gray. J. Am. Chem. Soc. 75, 2271 (1953).

18 is. R. Mardashev and L. A. Syomina. Dokl. Akad. Nauk SSSR 74, 537 (1950).

19 A. Meister and S. V. Tice. J. Biol. Chem. 187, 173 (1950).

20 A. Meister. In Methods in Enzymology. (Ed. Collowick and Kaplan), Vol. 2, p. 380, Acadernic Press, New York (1955).

21 J. Kon:. Nature 183, 1055 (1959).

22 R. Gmelin, G. Strauss, and G. Hasenmaier. Z. Physiol. Chem. 314, 28 (1959).

23 H. A. Krebs. Biochem. J. 29, 1951 (1935).

24 F. Lipinann and L. C. Tuttle. J. Biol. Chem. 159, 21 (1945).

25 H. Waelsch. Advan. Enzymol. 13, 237 (1952).

${ }^{26}$ W. H. Elliot. J. Biol. Chem. 201, 661 (1953).

27 J. M. Buchanan and S. C. Hartman. Advan. Enzymol. 21, 199 (1959).

28 U. Lagerkvist. J. Biol. Chem. 233, 138, 143 (1958).

${ }^{29}$ R. Abrams and M. Bentley. Arch. Biochem. Biophys. 79, 91 (1959).

30 H. S. Moyed and B. Magasanik. J. Biol. Chem. 226, 351 (1957).

31 A. H. Cook (Ed.) The Chemistry and Biology of Yeast, Academic Press, New York (1958).

32 H. Ratzkin and C. Ressler. Federation Proc. 22, 651 (1963). 